\title{
FARMAKOGENETIK PENGOBATAN BETA 2 AGONIST DAN STEROID PADA PENDERITA ASMA
}

\author{
EM Sutrisna \\ Bagian Farmakologi Fakultas Kedokteran \\ Bagian Farmakologi Fakultas Farmasi Universitas Muhammadiyah Surakarta \\ Korespondensi: Em.Sutrisna@ums.ac.id atau em_sutrisna@yahoo.com
}

\begin{abstract}
In the worldwide about 300 million people have asthma. $\beta-2$ agonists and steroids are widely prescribed drugs in the treatment of asthma. Different responses raises the suspicion of a genetic influence on the host's response to the treatment of this disease. The purpose of this review is to provide a comprehensive understanding of the influence of genetic factors on the treatment of asthma. This review is done by the method in Pubmed search using keywords Pharmacogenetic asthma; polymorphism beta agonist AND asthma. The analysis shows that there are several genes that affect treatment response. ADRB2 gene affects the bronchodilatation response for asthmatics treated with $\beta$-2 agonist. CRHR1 gene polymorphism, Glucocorticoid-complex genes, and CER2 genes and TBX21 genes affect the response to corticosteroids inhalers.
\end{abstract}

Keywords: Asthma, Pharmacogenetics, Treatment response

\section{PENDAHULUAN}

Asma merupakan gangguan respirasi yang didefinisikasn sebagai inflamasi kronis saluran nafas yang ditandai dengan responsivitas dari tracheobronkhila terhadap berbagai stimuli (McFadden, 2005). Diperkirakan Sebanyak 300 juta penduduk dunia terserang asma (Weiss, 2006). Gejala klinis dari asma terjadi karena edem dan infiltrasu dari berbagai sel seperyi eosinofil, netrofil dan limfosit. Gejala klinis tersebut terjadi karena interaksi yang simultan dari adanya infiltrasi sel-sel inflamasi, mediatormediator inflamasi dan sitokin. Sel-sel yang diduga berperan dalam inflamasi antara lain sel mast, eosinofil, limfosit, dan sel epitel jalan nafas. Salah satu mediator yang dikeluarkan pada asma adalah endotelin-1. Mediator ini memberikan efek bronkhokonstriksi. Sedang sitokin yang berperan antara lain GM-CSF, IL-8, Rantes (regulation on activation), eotaxin yang memberiakan efek inflamasi. Growth factor yang terlibat antara lain EGF (Epidermal growth factor), IGF-1 (Insulin like growth factor, dan PDGF (Platelet derivate growth factor) (McFadden, 2005).

Obat-obat untuk asma dikelompokan dalam dua kelompok yaitu obat yang menghambat konstriksi otot polos jalan nafas. Termasuk dalam kelompok ini adalah beta adrenergic agonist, methylxantin dan antikolinergik. Obat kelompok ini memberikan efek cepat. kelompok kedua merupakan longterm medication karena mempunyai efek mencegah dan atau menghilangkan inflamasi. Termasuk kelompok kedua ini adalah LABA (long acting beta 2 agonist glukokortikoid maupun methylxantin, stabilizer mast sel dan leukotrin modifiers) (McFadden, 2005).

Dalam perkembangannya ternyata didapatkan respon yang berbeda antar kelompok penderita asma dengan terapi yang sama. Variasi genetik memegang peranan penting dalam pengobatan asma.

\section{RESPON TERAPI PADA PENDERITA ASMA DENGAN VARIASI GENETIK BETA DUA AGONIS (B-2 AGONIST)}

$\beta-2$ agonist merupakan obat yang sangat umum diresepkan dalam pengobatan asma. Terdapat dua kelompok yaitu short acting dan long acting. Beta 2 agonis bekerja dengan cara mengikat beta 2 adrenergic receptor (Beta 2 AR). Beta 2 AR yang terangsang menyebabkan peningkatan produksi cyclic adenosine monophosphate (cAMP) dan protein kinase A 
(PKA). Hal ini menyebabkan relaksasi otot polos jalan nafas ( Johson, et al. 2006).

Beta 2 AR dikode gena ADRB2 (ADRB2 gene). Gen ini merupakan gen kecil yang terletak pada kromosom 5q31. Terdapat 80 polimorfisme pada gen ini dengan 45 SNPs (Single nucleotide polymorphism) dan 2 insersi /delesi yag telah divalidasi. Dua polimorfisme Non synonymous yang banyak berkaitan dengan respon $\beta-2$ agonist adalah 16 (Gly16Arg) dan 27 (Gln27Glu) ( Green et al., 1995, Green et al., 1995).

Studi yang dilakukan untuk mencari hubungan antara polimorfisme Gly16Arg memberikan hasil yang berbeda beda. Sejumlah studi menyatakan bahwa individu dengan homozigout 16Arg memberikan respon bonkodilatasi lebih baik dari homozigout Gly16 (Lima et al, 1999). Studi dengan hasil yang sama juga dilakukan oleh Martinez 1997 dan Choudhry 2005. Studi Martinez melibatkan 269 anak ras kaukasia dan Hispanic. Sebanyak 78 diantaranya menderita serangan wezzhing selama beberapa tahun terakhir ini. Dalam studi tersebut di dapatkan hasil bahwa anak dengan Homozigot Arg16 memberikan respon 5,6 kali lebih baik dari homozigot Gly16 pada pengobatan dengan albuterol. Sementara juga didapatkan tidak ada hubungan yang signifikan respon dilatasi bronchus dari anak dengan Glu27 dengan Gln27. Penelitian yang dilakukan Choudry melibatkan penderita asma dari ras Puoerto rican dan Mexican. Hasilnya adalah Pada penderita ras Puerto Rican didapatkan hasil penderita dengan Arg16 memberikan respon terapi terhadap albuterol lebih baik secara signifikan tetapi tidak pada ras Mexican. Studi oleh Israel yang melibatkan 190 penderita asma mendapatkan bahwa penderita dengan homozigot Arg16 mengalami penurunan PEFR (Peak expiratory flow rates ) pada pagi dan sore hari (Israel et al., 2000).

Hasil yang berbeda didapatkan dari penelitian tahun 2008 yang dilakukan oleh Blake et al. Dalam studi tersebut melibatkan lebih dari 500 pasien asma. Hasilnya adalah tidak ada hubungan antara SNPs pada ADRB2 dengan respon bronkodilatasi pada pasien asma (Blake et al., 2008)

Pada pemberian salmeterol (suatu LABA) yang dilakukan oleh Wechsler et al., 2006 menunjukkan hasil bahwa penderita asma dengan genotype homozigot Arg16 mengalami penurunan
PEFR dibanding dengan homozigot Gly16. Hasil berkebalikan dilakukan oleh Bleecker 2007 yang menyatakan tidak ada perbedaan respon antara Ag16 dan Gly16 pada pemberian Salmeterol. Studi Bleecker tahun 2010 yang melibatkan jumlah penderita asma 544 yang diberi salmeterol sendirian dan diberi salmeterol yang dikombinasikan dengan flutocasone propionate selama 16 minggu mendapatkan hasil bahwa baik pada penderita dengan Arg16 maupun Gly16 homozigot terjadi perbaikan PEFR pagi hari baik yang diberikan salmeterol sendirian maupun dikombinaskan dengan flutocasone propionate. Tidak ada perbedaan efek respon terhadap pemberian salmeterol antara penderita Arg16 dengan Gly16 (Bleecker et al. 2010). SNPs pada ADRB2 dimana terjadi subtitusi arginin ke glysin meningkatkan responsivitas terapi albuterol/ salmeterol. Pemakaian jangka panjang $\beta-2$ agonist berhubungan dengan pemburukan fungsi paru dan peningkatan eksaserbasi asma (YU et al, 2008). Varian ADRB2 berupa Ile164 dan insersi basa -376 (-376ins) meningkatkan resiko efek samping jika diberikan LABA (Ortega et al., 2014)

\section{KORTIKOSTEROID}

Kortiskosteroid terutama dalam bentuk inhaler merupakan terapi asma yang sangat efektif bahkan merupakan terapi lini pertama (first line) pada asma persisten. Suatu studi yang dilakukan oleh Tantisira et al, 2004 menyatakan bahwa terdapat hubungan signifikan CRHR1 (Corticotropin-releasing hormone receptor 1) dengan respon terhadap terapi steroid inhaler. Pasien homozygot pada minor allele rs242941 (Minor allele frequency < 30\%) memiliki perubahan dalam FEV1( Forced expiratory volume) secara signifikan setelah terapi steroid inhalasi (2-3x) dibanding tanpa variant (Tse et al, 2010).

Kandidat polimorfisme lain adalah pada Glukokortikoid receptor. Dilaporkan ditemukan SNPs dalam 8 Glucocorticoid-complex genes pada 382 populasi kulit putih yang mendapat terapi Inhaler corticosteroids (ICs). Dia menemukan terdapat beberapa SNPs di gen STIP1 ( Stress induced phosprotein-1) yang berhubungan dengan persen perubahan FEV1 setelah pengobatan ICs 4 dan 8 minggu (Hawkins et al., 2009). Rs6591838 berkorelasi dengan peningkatan paling besar dalam FEV1 $(20.70 \% \pm 28.29 \%)$ setelah pengobatan 8 minggu pada allel GG (Hawkins et al., 2009) 
Gena lain adalah FCER2 gene (Fc epsilon RII) yang mengkode CD23. Dimana CD23 mempunyai afinitas yang rendah terhadap $\operatorname{Ig} E$ receptor dan glukokortikoid yang ditunjukkan dengan ekspresi FCER2 dan produksi CD23. (Fischer et al., 1990). Variant FCER2 yang disebut T2206C dilaporkan berhubungan dengan peningkatan kadar igE pada anak dengan asma eksaserbasi berat meskipun menggunakan ICs. Penderita asma anak dengan homozigot mutant allele T2206C 3,95 kali lebih besar (95\% CI 1.649.51) terserang asma exaxerbasi berat (Tantisira et al., 2007)

Gen TBX21 (T-box trnascripstion factor 21) mengkode nuclear transcription factor T-bet. T-bet inilah yang bertanggung jawab atas diferensiasi naive $\mathrm{T}$ limfosit ke dalam sel Th1 sementara secara bersamaan menekan sel Th2 (Szabo, 2000). Penderita asma memiliki penurunan ekspresi T-bet secara signifikan di CD4 +limfosit peribronchialnya ( Finnoto, et al. 2002). Rs2240017, suatu variasi nonsynonymous pengkode penggantian histidin 33 dengan glutamin (H33Q, MAF 4,5\% ras Kaukasia), telah dikaitkan dengan respon yang meningkat pada jalan nafas pada anak yang mendapat terapi ICs (Tantisira et al., 2004).

\section{SIMPULAN:}

1. Terapi $\beta-2$ agonist dan kortikosteroid penderita asma bersifat individual

2. Polimorfisme pada gen ADRB2 mempengaruhi respon bronkhodilatasi penderita asma

3. Polimorfisme gen CRHR1, Glucocorticoidcomplex genes, gen CER 2 dan gen Gen TBX21 mempengaruhi respon terhadap pemberian kortikosteroid inhaler

\section{DAFTAR PUSTAKA}

Antisira KG, Hwang ES, Raby BA, Silverman ES, Lake SL, Richter BG, et al. TBX21: afunctional variant predicts improvement in asthma with the use of inhaled corticosteroids. Proc Natl Acad Sci U S A. 2004; 101(52):18099_ 18104

Blake KV, Feng H, Tantisira K, et al. Bronochodilator response and $\mathrm{B} 2$-adrenergic receptor ADRB2 haplotype tagging single nucleotide polymorphisms (htSNPs) [abstract]. Am J Respir Crit Care Med 2008;177:A568.

Bleecker ER, Nelson HS, Kraft M, Corren J, Meyers DA, Yancey SW, et al. Beta2-receptor polymorphisms in patients receiving salmeterol with or without fluticasone propionate. Am J Respir Crit Care Med. 2010; 181(7):676-687. [PubMed: 19910613]

Bleecker ER, Postma DS, Lawrance RM, Meyers DA, Ambrose HJ, Goldman M. Effect of A DRB2 polymorphisms on response to longacting beta2-agonist therapy: a pharmacogenetic analysis of two randomised studies. Lancet. 2007; 370(9605):2118-2125. [PubMed: 18156033]

Choudhry S, Ung N, Avila PC, et al. Pharmacogenetic differences in response to albuterol between Puerto Ricans and Mexicans with asthma. Am J Respir Crit Care Med 2005;171:563570. [PubMed:15557128]

Finotto S, Neurath MF, Glickman JN, Qin S, Lehr HA, Green FH, et al. Development of spontaneous airway changes consistent with human asthma in mice lacking T-bet. Science. 2002;295(5553):336-338.

Fischer A, Konig W. Regulation of CD23 expression, soluble CD23 release and immunoglobulin synthesis of peripheral blood lymphocytes by glucocorticoids. Immunology. 1990; 71(4):473-479.

Green SA, Turki J, Bejarano P, et al. Influence of beta 2 -adrenergic receptor genotypes on signal transduction in human airway smooth muscle cells. Am J Respir Cell Mol Biol 1995;13:25-33.[PubMed: 7598936]

Green SA, Turki J, Innis M, Liggett SB. Aminoterminal polymorphisms of the human beta 2- adrenergic receptor impart distinct agonist-promoted regulatory properties. Biochemistry 1994;33:94149419. [PubMed: 7915137](Erratum in Biochemistry 1994 29; 33:14368)

Hawkins GA, Lazarus R, Smith RS, Tantisira KG, Meyers DA, Peters SP, et al. The glucocorticoid receptor heterocomplex gene STIP1 is associated with improved lung function in asthmatic subjects treated with inhaled corticosteroids. J Allergy Clin Immunol. 2009; 123(6):1376-1383.e1377

Israel E, Drazen JM, Liggett SB, Boushey HA, Cherniack RM, Chinchilli VM, et al. The effect of polymorphisms of the beta(2)adrenergic receptor on the response to regular use of albuterol in asthma. Am J Respir Crit Care Med. 2000; 162(1):75-80. [PubMed: 10903223]

Johnson M. Molecular mechanisms of beta(2)adrenergic receptor function, response, and 
regulation. J Allergy Clin Immunol. 2006; 117(1):18-24. quiz 25. [PubMed: 16387578]

Lima JJ, Mohamed M, Eberle LV, et al. Impact of genetic polymorphisms of the $\beta 2$-adrenergic receptor on albuterol bronchodilator pharmacodynamics. Clin Pharmacol Ther 1999;65:519-525. [PubMed: 10340917]

Martinez FD, Graves PE, Baldini M, et al. Association between genetic polymorphisms of the beta2- adrenoceptor and response to albuterol in children with and without a history of wheezing. J Clin Invest 1997;100:31843188. [PubMed: 9399966]

McFadden, ER. Asthma, dalam Kasper et al., The Principles of internal medicine ed 16. McGrawhill. 2005.NewYork.1508-12

Ortega VE, Hawkins GA, Moore WC, Hastie AT, AmplefordEJ, BusseWW, CastroM, Chardon D, Erzurum SC, Israel E, Montealegre F, Wenzel SE, Peters SP, Meyers DA, Bleecker ER. Effect of rare variants in ADRB2 on risk of severe exacerbations and symptom control during longacting $\beta$ agonist treatment in a multiethnic asthma population: a genetic study.

Lancet Respir Med. 2014 Mar;2(3):204-13. doi: 10.1016/S2213-2600(13)70289-3. Epub 2014 Jan 27.

Syamsu, Yusuf I, Budu, Patellongi I. The effect of polymorphism of the beta-2 adrenergic receptor on the response tobeta-2 agonist in bronchial asthma patients.

Acta Med Indones. 2007 Jan-Mar;39(1):8-12

Szabo SJ, Kim ST, Costa GL, Zhang X, Fathman CG, Glimcher LH. A novel transcription factor, T-bet, directs Th1 lineage commitment. Cell. 2000; 100(6):655-669

Tantisira KG, Lake S, Silverman ES, Palmer LJ, Lazarus $\mathrm{R}$, Silverman EK, et al. Corticosteroid pharmacogenetics: association of sequence variants in CRHR1 with improved lung function in asthmatics treated with inhaled corticosteroids. Hum Mol Genet. 2004; 13(13):1353-1359

Tantisira KG, Silverman ES, Mariani TJ, Xu J, Richter BG, Klanderman BJ, et al. FCER2: a pharmacogenetic basis for severe exacerbations in children with asthma. J Allergy Clin Immunol.2007; 120(6):12851291.

Tantisira KG, Small KM, Litonjua AA, Weiss ST, Liggett SB. Molecular properties and pharmacogenetics of a polymorphism of adenylyl cyclase type 9 in asthma: interaction between beta-agonist and corticosteroid pathways.

Hum Mol Genet. 2005 Jun 15;14(12):1671-7. Epub 2005 May 6.

Taylor DR, Drazen JM, Herbison GP, Yandava CN, Hancox RJ, Town GI. Asthma exacerbations during long term beta agonist use: influence of beta(2) adrenoceptor polymorphism.

Thorax. 2000 Sep;55(9):762-7.

Wechsler ME, Lehman E, Lazarus SC, Lemanske RF Jr, Boushey HA, Deykin A, et al. betaAdrenergic receptor polymorphisms and response to salmeterol. Am J Respir Crit Care Med. 2006; 173(5):519-526. [PubMed: 16322642]

Weiss ST, Litonjua AA, Lange C, Lazarus R, Liggett SB, Bleecker ER, Tantisira KG. Overview of the pharmacogenetics of asthma Treatment, The Pharmacogenomics Journal (2006) 6, $311-326$

Yu IW, Bukaveckas BL. Pharmacogenetic tests in asthma therapy. Clin Lab Med. 2008 Dec;28(4):645-65. doi: 10.1016/j. cll.2008.05.001. 